\title{
Small-Medium Enterprises (SMEs) Batik Tulis in Jetis Village, District of Sidoarjo
}

\author{
Author \\ Ong Andre Wahyu Riyanto, Slamet Riyadi, Maya Ida Kusuma \\ Correspondence \\ Universitas Wijaya Putra Surabaya, STIE Mahardhika Surabaya \\ ongandre@uwp.ac.id
}

doi : 10.30587/kontribusia.v1i1.249

URL:http://dx.doi.org/10.30587/kontribusia.v1i1.249

\begin{abstract}
This activity program aims to increase the efficiency of marketing business management SMEs batik Tulis in Sidoklumpuk village, Jetis Lemahputro, Sidoarjo District. The targets to be achieved for this program, include: 1) creating online commercial sales system to expand access marketing batik product to foreign countries, as well as providing convenience for customers as well as SMEs in conducting business transactions. 2) Creating logo design for the product packaging common local wisdom of kampong batik Jetis to strengthen the brand. So that SMEs are expected to develop into business to meet customer demand and survive in a competitive business climate. The utilization of e-commerce web for SMEs batik around Jetis. Jetis Batik can be a characteristic of great micro business in Jetis Village. The local government is expected to provide support for the success of the SMEs independently initiated programs collectively.
\end{abstract}

Keywords: SMEs, Batik Jetis, e-commerce

\section{Introduction}

The business market has been defined to include organizations that buy products and services for use in the production of other products and services that are sold, rented or supplied to others. It also includes retailing and wholesaling firms that acquire goods to resell or rent to others (Zimmerman and Blythe, 2013). The primary process of planning is having decided on a strategic direction and position; marketers need to consider how to marshal the tools at their disposal to achieve the desired strategic outcome (Zimmerman and Blythe, 2013).

Many devotional programs have been widely implemented in eastern Java both in the community sector, SMEs, and industry, among others: improving skills to manage household waste in Wonokromo urban villages, Surabaya (Kunhadi et al., 2018). Implementation of quality control circle method (Riyanto, 2015). System model simulation is working to minimize work-inprocess time (Riyanto, 2016). Meaningful experience of motivation to power seller with orientation on consumer satisfaction for identification of employee benefits in the textile sales in south Surabaya (Puspitasari and Harjanti, 2017). Also, the role of chippy processing industry
Received: 10 April 2018. Accepted: 25 June 2018

"tempe geti" in Ngawi regional economy (Kunhadi and Harjanti, 2017).

Sidoarjo is one of the big cities in East Java. His name was famous when the mud disaster struck the city. Geographically, the city of Sidoarjo lies between two major rivers, the Porong river, and Surabaya river so that making it famous as the city of Delta.

The growth of SMEs (Small Medium Enterprises) Sidoarjo regency continued to increase sharply enough. In 2013 the number of SMEs had reached 169 thousand businesses. Besides, there are about 85 industrial centers, in addition to 11 business villages, namely snack products, batik products, culinary ducks, krupuk, also mushroom culinary, and other products, so that get a variety of appreciation from the government.

The excellent potential of Sidoarjo Regency can be developed and has competed in the domestic and global market, because of its trademark, quality, and competitive price. Besides, the excellent potential comes from natural resources and potential local cultural resources. The real effort of Sidoarjo Regency Government in exploring the excellent potential is by launching several business centres in Sidoarjo regency, one 
of them is Kampoeng Batik in Jetis Village, Sidoarjo Subdistrict. Jetis Village with its batik products is one of One Village One Product's (OVOP) developed by the East Java government (Saputra, 2015).

Batik Jetis has existed since 1675. Batik was brought by Mbah Mulyadi, the descendant of King Kediri. However, the development of the batik Jetis product business appeared in the 1950s. In 1956 batik company Mrs Musyafa'ah (the oldest batik business in Jetis village) was officially established. From here batik business began to be home-based business Jetis society. The business became their main livelihood for many years till now.

During this SMEs of batik still, complain about the sale of products conventionally by offering directly to buyers in their gallery/shop. Such sales activity constrains the market potential that can be reached. A practical, efficient, and competitive marketing breakthrough is needed to increase their sales reach of batik products of SMEs in Jetis kampong.

\section{Problem Identification}

Currently, the SMEs batik products are still selling their products in a conventional manner where the buyer directly visited the gallery/shop in the village of batik Jetis. Urgent problems in SMEs Batik Jetis are a) Marketing is still conventional. b) Branding Batik Jetis not optimal and c) The report of the financial administration of business still roughing.

The interactive e-commerce website for SMEs Kampong Batik Jetis will be able to expand marketing access and provide convenience for customers as well as SMEs batik product in conducting business transactions.

The role of Interactive e-commerce design to increase sales potential will simplify product sales transactions and provide convenient and fast service for customers. A business-to-customer ecommerce web. Also, Product logo design can increase the branding of the Jetis batik product.

\section{Method}

The methods used in this activity program are:

a. Interactive e-commerce design to increase sales potential, simplify product sales transactions, and provide fast and convenient service for customers.

b. Product logo design of the batik product of the Kampong Jetis.

c. Implementation of financial report model based on production activities.

The design of the e-commerce is shown in figure 1 until figure 11 this below.

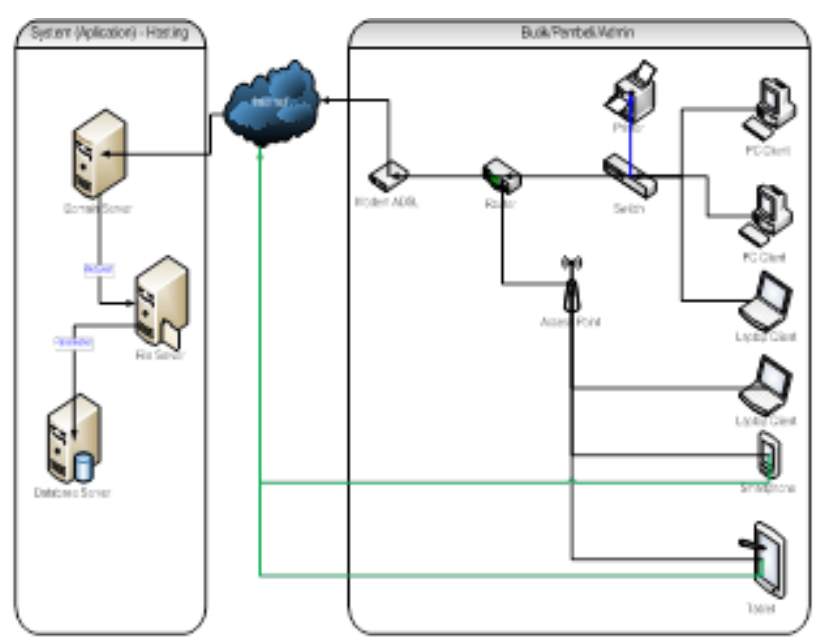

Figure 1. Design of the E-commerce System

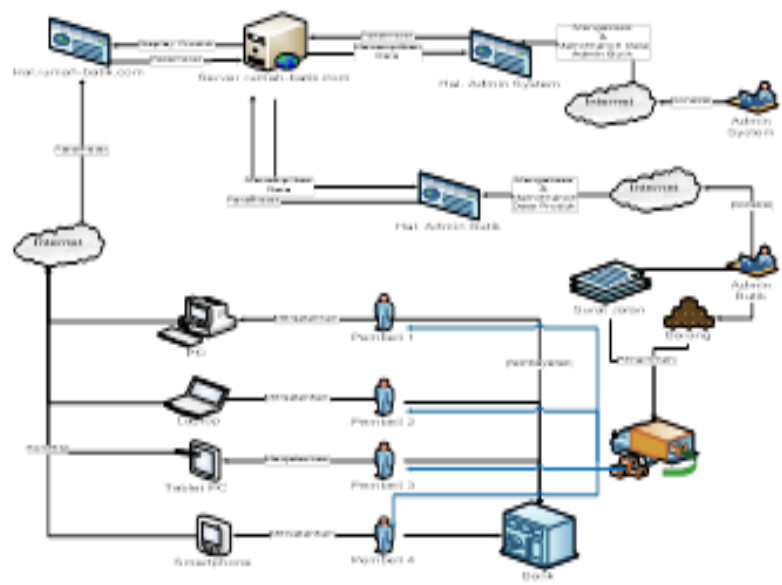

Figure 2. Business Process Flow E-commerce 


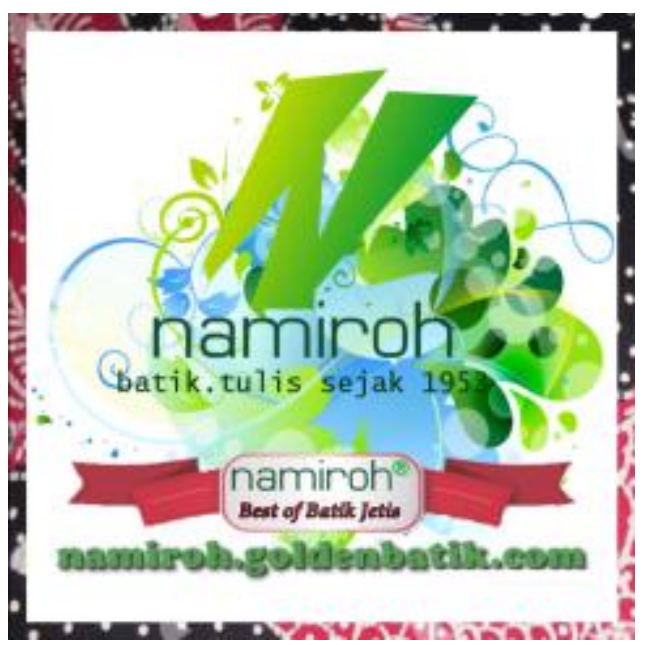

Figure 3. Design Logo Packaging of the

"Namiroh Batik Tulis"

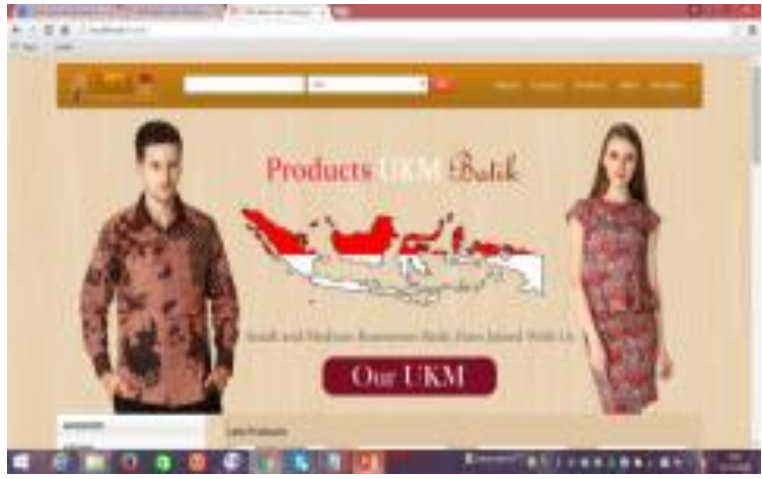

Figure 4. Web E-commerce of the "Namiroh Batik Tulis"

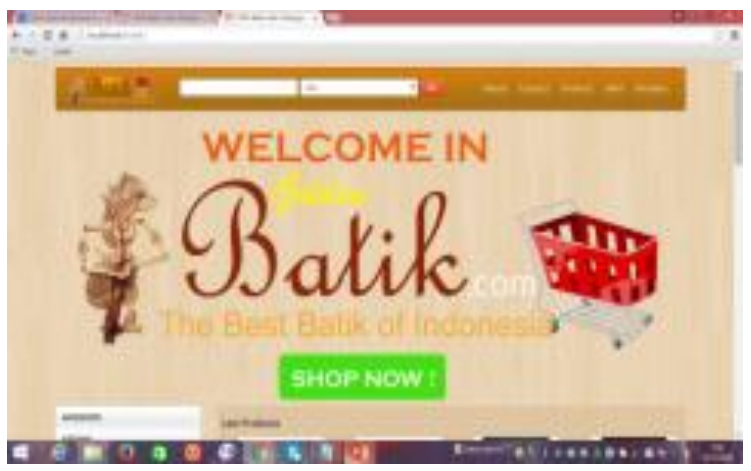

Figure 5. Web E-commerce of the "Namiroh Batik Tulis"

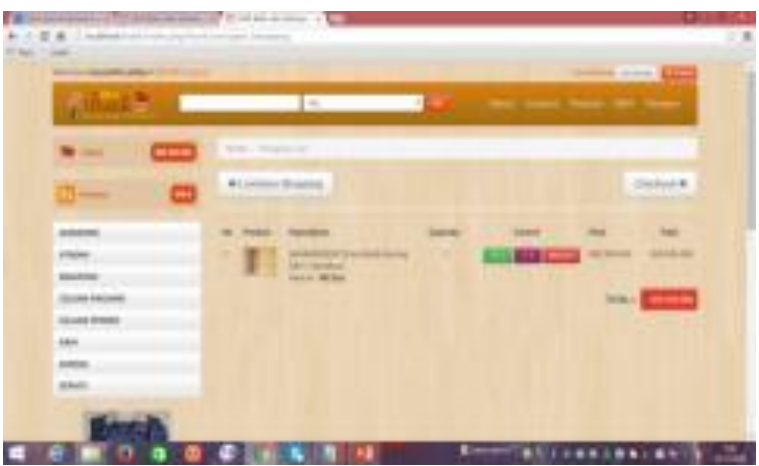

Figure 6. Web E-commerce of the "Namiroh Batik Tulis"

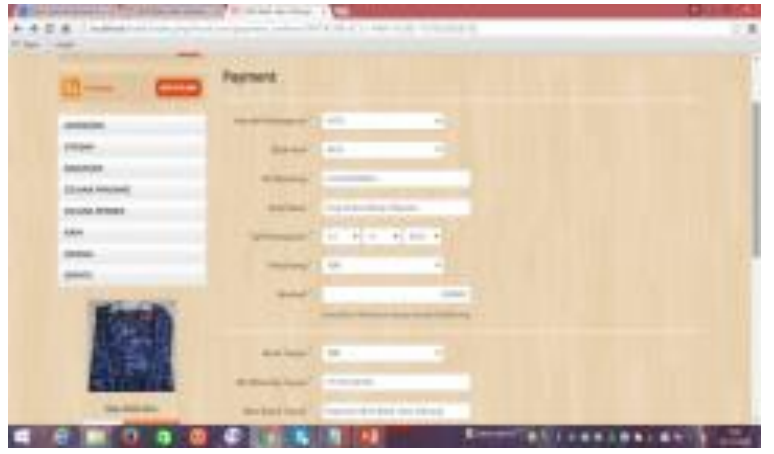

Figure 7. Web E-commerce of the "Namiroh Batik Tulis"

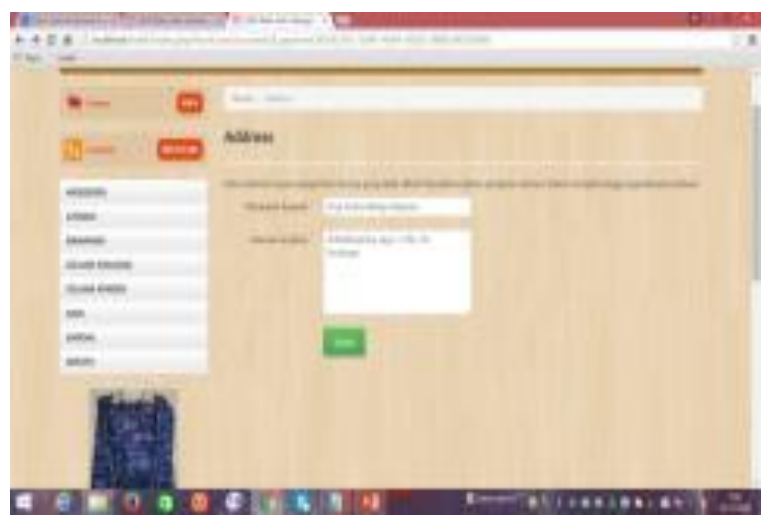

Figure 8. Web E-commerce of the "Namiroh Batik Tulis"

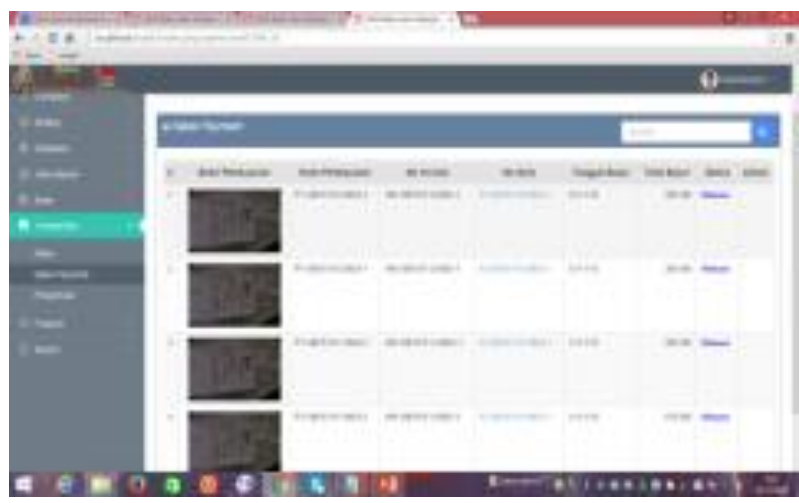

Figure 9. Web E-commerce of the "Namiroh Batik Tulis"

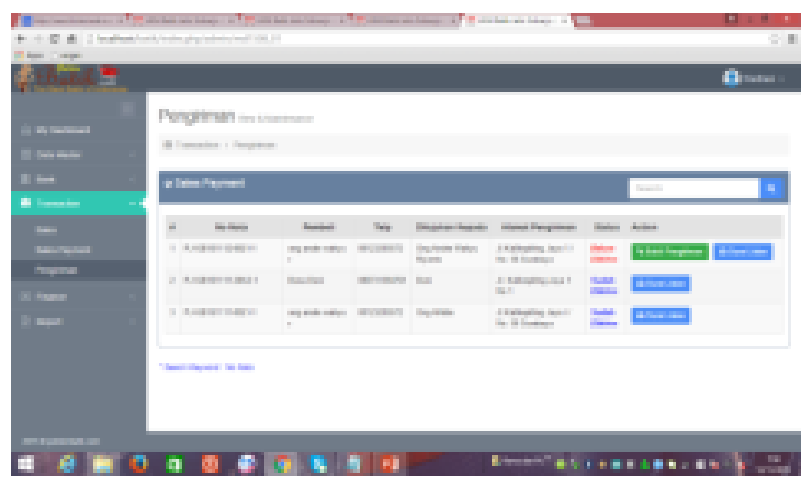


Figure 10. Web E-commerce of the "Namiroh Batik Tulis"

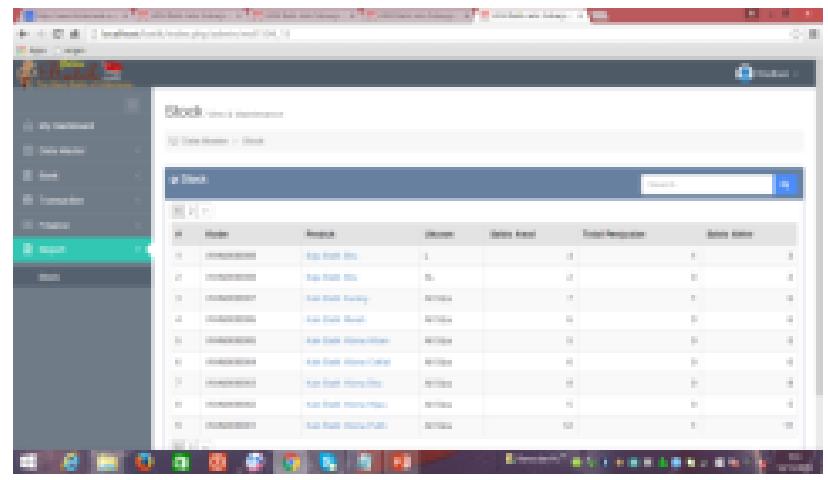

Figure 11. Web E-commerce of the "Namiroh Batik Tulis"

\section{Results and Discussion}

The utilization of e-commerce web for SMEs batik jetis around. Jetis Batik can be a characteristic of great micro business in Jetis Village. The local government is expected to provide support for the success of the SMEs independently initiated programs collectively.

The role of Interactive e-commerce design to increase sales potential will simplify product sales transactions and provide convenient and fast service for customers. A business-to-customer ecommerce web. Also, Product logo design can increase the branding of the Jetis batik product.

\section{Acknowledgement}

The work presented in this paper was funded from Ministry of Technology Research and Higher Education of Indonesia with namely the "Technology for society" scheme in the 2015 year. We wish to express our highest appreciation for the Ministry of Technology Research and Higher Education of Indonesia for funding this work. We are also grateful to Wijaya Putra University.

\section{Conclusion}

The Conclusion that can be obtained from the implementation of a community service program, which targets the empowerment of SMEs of the batik product, are:

a. Utilization of e-commerce web is expected to increase the sales rate of the Jetis batik SMEs.

b. Improving image/branding of SMEs of the Jetis batik products.

c. The high participation rate of the program partners has a positive impact on program implementation.

Based on the transfer of technology that has been implemented some suggestions that are worthy of consideration, namely: Partners SMEs of the Jetis batik product can be into informants in this business.

\section{References}

Kunhadi, D., \& Harjanti, W. (2017). Peranan Industri Pengolahan Kripik" Tempe Geti" Dalam Menggerakkan Perekonomian Daerah Ngawi. EKUITAS (Jurnal Ekonomi dan Keuangan), 12(3), 401-416.

Kunhadi, D., Badriyah, B., \& Atmajawati, Y. (2018). Improving Skills to Manage Household Waste in Wonokromo Urban Village, Surabaya. Kontribusia (Research Dissemination for Community Development), 1(1), 43-46.

Puspitasari, E., \& Harjanti, W. (2017). Meaningful Experience of Motivation to Power Seller with Orientation on Consumer Satisfaction for Identification of Employee Benefits in the Textile Sales in South Surabaya. IJEBD (International Journal of Entrepreneurship and Business Development), 1(1), 1-22.

Riyanto, O. A. W. (2015). Implementasi Metode Quality Control Circle untuk Menurunkan Tingkat Cacat pada Produk ALLOY WHEEL. Journal of Engineering and Management in Industrial System, 3(2).

Riyanto, O. A. W. (2016). Simulasi Model Sistem

Kerja Pada Departemen Injection Untuk Meminimasi Waktu Work-In-Process. Jurnal Ilmiah Teknik Industri, 15(1), 69-78.

Saputra, A. K. (2015). Analisis Spesialisasi Dan Konsentrasi Spasial Industri Kecil Menengah Di Jawa Timur (Doctoral dissertation).

Singgih, M. L. (2012). Green Productivity Konsep dan Aplikasi.

Zimmerman, A., \& Blythe, J. (2013). Business to business marketing management: A global perspective. Routledge. 